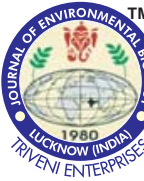

\title{
Characterization and management of Botrytis cinerea inciting blossom blight of carnation under protected cultivation
}

Authors Info

S. Vinodkumar and S. Nakkeeran* Department of Plant Pathology, Centre for Plant Protection Studies, Tamil Nadu Agricultural University, Coimbatore-641 003, India

${ }^{*}$ Corresponding Author Email : nakkeeranayya@gmail.com

Key words

Botrytis cinerea,

Blossom blight,

Environmental factors,

Fungicides

Protected cultivation

Publication Info

Paper received : 02.05.2016

Revised received : 14.10 .2016

Re-revised received : 16.11 .2016

Accepted: 07.12 .2016

\section{Abstract}

Aim : The present study aimed to characterize the pathogen responsible for blossom blight of carnation, as well as to manage the disease effectively using fungicides. The investigation also included the study about the developmental biology of the pathogen in relation to environmental factors.

Methodology : The pathogen was exposed to various environmental factors viz., light, relative humidity, temperature in order to assess their relation. Identity of the pathogen was characterized by sequencing the 18S-28S rRNA genes. Efficacy of the fungicides was studied by in-vitro poisoned food technique. Their efficacy under protected cultivation was assessed through foliar spray.

Results : Field survey revealed severe blossom blight incidence at Nilgiris district, Tamil Nadu, India. Under in vitro conditions, the pathogen sporulated profusely at $15^{\circ} \mathrm{C}$, when exposed to alternate light and dark hours. The pathogen produced, scattered, large, dark, black, irregular, flat, smooth surfaced, sclerotial bodies, under dark at $20^{\circ} \mathrm{C}$. Morphological characterization and sequencing of the 18S-28S rRNA genes identified the pathogen to be Botrytis cinerea. Tebuconazole effectively inhibited the growth of the pathogen in vitro @ 5ppm concentration. Blossom blight incidence under protected cultivation was curtailed to a greater extent by foliar spray with tebuconazole.

Interpretation : Blossom blight caused by $B$. cinerea is an important post harvest pathogen that leads to huge loss. The present study regarding the relationship of environmental factors with the developmental biology of the pathogen provides sufficient scope for future studies in designing effective management practices. Moreover, application of tebuconazole drastically reduced blossom blight incidence under protected cultivation.

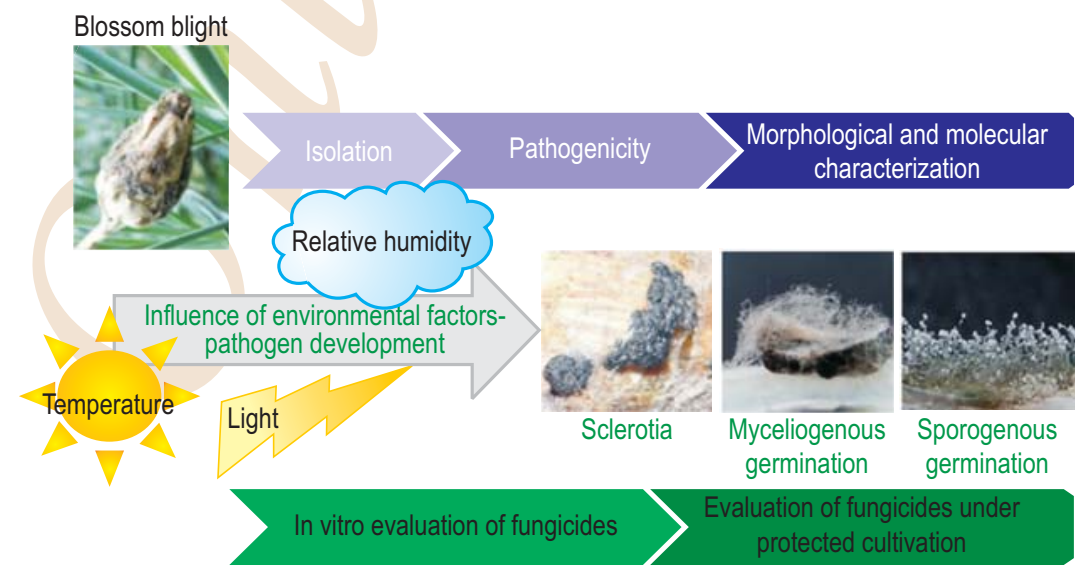




\section{Introduction}

Carnation is one among the flowers known to tyrannize global cut flower market. World's affinity towards carnation has increased due to wide variety of available colours and long shelf life. Carnations are affected by many diseases that drastically reduce the quality of the produce. Blossom blight caused by Botrytis cinerea has highly destroying nature. The pathogen is fast growing and covers the entire flower with grey mycelium during storage and transport. Botrytis cinerea is an important pathogen that creates great problem in stored and transported fruits, vegetables, and ornamental crops, (Jarvis, 1977). The host range of $B$. cinerea comprises over 200 plant species, including important protein, oil, fibre and horticultural crops. Infection is common in temperate and subtropical regions (Williamson et al., 2007).

Climatic condition plays a major contribution in disease establishment as well as growth and development of the pathogen. Botrytis is common and economically important pathogen among various polyhouse-grown cut flowers. Botrytis and its sexual form Botryotinia fuckeliana comprise 22 species and one hybrid (Hennebert, 1973; Yohalem et al., 2003). The fungus exhibits various morphogenic forms viz., mycelia, microconidia, macro-conidia, chlamydospores, sclerotia, apothecia and ascospores. Infective propagules are dispersed by diverse means based on their nature (Jarvis, 1980). Blossom blight being a storage pathogen, cause severe loss to the cut flower industry. In order to restrict the loss and damage caused by the disease, thorough knowledge about the growth and developmental of the pathogen is essential. Thus, the current investigation focus on the environmental factors involved in the growth and development of the pathogen. Moreover, management of blossom blight with effective chemical molecules has been studied in detail.

\section{Materials and Methods}

Survey and symptomatology : Carnation varieties were surveyed for the occurrence of blossom blight in Ooty and Kothagiri regions of Nilgiris district in Tamil Nadu, India during 2013. Commercially cultivated varieties viz., Yellow Liberty, Gaudinared, Farida, Bizet, Emotion white, Pintado, White Liberty, Charmant pink, Pudding yellow and Baltico white cultivated at Ooty and Kothagiri (Kothagiri, Nedugula, Kodanad), under protected condition were surveyed. All together a total of 30 farms were surveyed in and around Nilgiris and the mean PDI of the varieties are represented. Blossom blight incidence was assessed by calculating Percent Disease Incidence by the following formula (Wheeler, 1969)

Percent disease incidence $=\frac{\text { No of plant showing symptoms }}{\text { Total no of plants observed }} \times 100$

Plants expressing symptoms of blossom blight under protected cultivation were visualised and described. Life cycle of
B. cinerea was assessed by inoculating mycelium and spore suspension on the flowers of carnation variety Gaudina red.

Isolation and pathogenicity : The pathogen was isolated from the infected floral parts characterized by the presence of grey mycelium with profuse sporulation, as well as from sclerotial bodies (Chilvers and Toit, 2006). Surface sterilization was performed with $0.5 \%$ sodium hypochlorite $(\mathrm{NaOCl})$. After isolation the Petri plates were incubated at $20 \pm 2{ }^{\circ} \mathrm{C}$ for $5-6$ days and observed periodically for the growth of pure colonies. The pathogen was purified by single hyphal tip method and multiplied for future studies.

Pathogenicity experiments were conducted by inoculating conidial suspension. Conidial suspension was prepared in phosphate buffer $(\mathrm{pH} 7) @ 4.6 \times 10^{4}{\text { conidia } \mathrm{ml}^{-1} \text { and }}^{-1}$ sprayed over healthy flower buds with a hand atomizer. Control, sprayed with blank phosphate buffer was also maintained (Rivera and Wright, 2002). The experiments were replicated thrice with five flower buds per replication. After inoculation, the plants were covered with polythene bags and incubated at ambient environmental conditions inside the poly houseat Elkhill Agro Pvt. Ltd., Nilgiris for 10 days.

Pathogenicity was also experimented in vitro by detached flower technique. Spore suspension containing $4.6 \times 10^{4}$ conidia $\mathrm{ml}^{-1}$ of phosphate buffer ( $\mathrm{pH} 7$ ) was sprayed over 10 healthy flower buds using a hand atomizer. Similarly 5 flower buds, sprayed with blank phosphate buffer were also maintained as control. After inoculation the flowers were covered in moistened polythene bags and incubated at $4{ }^{\circ} \mathrm{C}$, in dark for 10 days. After the appearance of symptoms, the pathogen was re-isolated in order to confirm Koch's postulates.

Identification : The pathogen was identified by morphological and molecular characterization. Morphological characterization was attempted based on the key characteristics (Table 1) proposed in earlier studies (Chilvers and Toit, 2006; Zhang et al., 2010; Persly, 1985).

Species differentiation was executed based on the relative growth rate, sporulating temperature and sclerotial productions. Biology of the pathogen was compared with well documented species of Botrytis viz., B. aclada, B. allii, B. byssoidea, B. cinerea, B. squamosa, B. porriand B. fabae.

Molecular characterization : The fungus was subjected for molecular characterization by sequencing the 18S-28S rRNA genes. The genomic DNA was extracted by Cetyl Trimethyl Ammonium Bromide (CTAB) method (Chakraborty et al., 2010).

PCR amplification of 18S-28S rRNA gene and sequencing: The genomic DNA was used as a template and subjected for PCR amplification of 18S-28S rRNAgene. ITS 1 (5'-TCCGTAGGTGAA CCTGCGG-3') and ITS 4 (5'-TCCTCCGCTTATTG ATATGC-3') 
Table 1 : Key for the identification of Botrytis species based on morphology

\begin{tabular}{llll}
\hline Botrytis species & Growth rate & Optimum sporulating temperature $\left({ }^{\circ} \mathrm{C}\right)$ & Sclerotial production \\
\hline B. allii & Intermediate & 20 & - \\
B. byssoidea & Intermediate & 15 & - \\
B. squamosa & Intermediate & 5 & Numerous, small, black \\
B. fabae & Intermediate & 4 & Numerous, small, black \\
B. porri & Fast & - & Medium to large, brown, surface cerebriform. \\
B. cinerea & Fast & 15 & Scattered, medium to large, smooth surface, dark black \\
\hline
\end{tabular}

primer pair (White et al., 1990) was used to amplify the 18S-28S rRNAgene as per the protocol of Saitoh et al., 2006. The amplified PCR product was sequenced by Sanger dideoxy sequencing method at Excelris genomics, Ahmedabad. Further phylogenetic tree was constructed with the 18S-28S rRNA gene sequences retrieved from $\mathrm{NCBI}$. Maximum neighbor joining tree was constructed with Mega 7.0 with 1000 boot strap replications with a cut off value of $50 \%$.

Influence of environmental factors on the growth parameters of $\boldsymbol{B}$. cinerea: Developmental biology of Botrytis spp., is influenced by various environmental factors. To assess the influence of temperature and light on the growth parameters of $B$. cinerea, the plates were incubated at six different temperatures viz., $5^{\circ} \mathrm{C}, 10^{\circ} \mathrm{C}, 15^{\circ} \mathrm{C}, 20^{\circ} \mathrm{C}, 25^{\circ} \mathrm{C}$ and $30^{\circ} \mathrm{C}$ under complete light, complete darkness and alternate light and dark. In order to assess the influence of relative humidity on sporulation, sclerotial bodies in glass slides were incubated in moist chamber at $15^{\circ} \mathrm{C}$ with alternate light and dark (Chilvers and Toit, 2006).

Treatments were subsequently executed one by one, based on the results of previous treatments viz., Initially the pathogen was incubated at $5^{\circ} \mathrm{C}, 10^{\circ} \mathrm{C}, 15^{\circ} \mathrm{C}, 20^{\circ} \mathrm{C}, 25^{\circ} \mathrm{C}$ and $30^{\circ} \mathrm{C}$ under complete darkness in order to assess the influential effect of temperature on mycelial growth. Treatments that produced optimum mycelial growth $\left(15^{\circ} \mathrm{C}\right.$ and $\left.20^{\circ} \mathrm{C}\right)$ were selected and proceeded for combinatorial treatment with light viz., plates were incubated at $15^{\circ} \mathrm{C}$ and $20^{\circ} \mathrm{C}$ separately and exposed to complete light, complete darkness and alternate light and dark. As per the result of this combinatorial treatment, optimum light condition and temperature (i.e. $15^{\circ} \mathrm{C}$ with alternate light and dark) was selected and proceeded towards testing of the influence of relative humidity in sporulation. Sclerotia of $B$. cinerea were placed over sterile glass slides inside Petri plates, layered with moist cotton and incubated at $15^{\circ} \mathrm{C}$ with alternate light and dark. Subsequently control plate without any moist cotton was also maintained. Each treatment was replicated thrice.

In vitro evaluation of fungicides against $B$. cinerea: Efficacy of six fungicides viz., carbendazim (75\% WP), tebuconazole (250EC), difenoconazole (25\%), propineb (70WP), tebuconazole $(50 \%)+$ trifloxystrobin $(25 \%)$, azoxystrobin $(25 \%$ SC) were tested against $B$. cinerea by poisoned food technique, using the product available in the market. Potato dextrose agar medium was amended with 1ppm, 5ppm, 10 ppm, 25ppm, 50ppm, 100ppm, 250ppm, 500ppm and 1000ppm of fungicides and poured separately in a Petri plate and allowed for solidification. Three day old mycelial discs of $B$. cinerea was placed in the middle of the Petri plates and incubated at $\left(20 \pm 2{ }^{\circ} \mathrm{C}\right)$. Appropriate control for each was also maintained without adding fungicides. The treatments were replicated thrice. Diameter of the colonies was recorded on $3^{\text {rd }}$ day after the control plate was completely covered with mycelium. Percent inhibition of mycelial growth of the pathogen was calculated by the formula given by Dennis and Webster (1971).

Evaluation of fungicides against blossom blight of carnation variety Gaudina red under protected cultivation: Field experiment was conducted during 2013-2014 at Nilgiris to assess the efficacy of fungicides against $B$. cinerea under protected condition. The plants were sprayed with fungicides viz., carbendazim 50\% WP, tebuconazole 250 EC, difenoconazole $25 \%$ EC, propineb $70 \mathrm{WP}$, propiconazole $25 \%$ EC and azoxystrobin 25\% SC at weekly interval @ 0.15\%. The experiment was replicated thrice with 30 feet long bed. Subsequently, an untreated control was also maintained. Number of healthy flowers and infected flowers were calculated. Observations were recorded with three replications for each treatment and expressed as numbers per $\mathrm{m}^{2}$.

\section{Results and Discussion}

Survey : Survey results revealed that highest incidence (9.4\%) was observed at Kothagiri in gaudina red variety, followed by gaudina red, the variety, charmant pink had 6.4 PDI. However, other varities had PDI ranging from 2.6 to 4.6. The mean PDI at Kothagiri (4.49) was greater than the mean PDI at Ooty. Greater relative humidity prevailing in Kothagiri favoured the occurrence of blossom blight compared to other regions of Nilgiris (Table 2).

Symptomatology : Symptoms were found only during flowering stage. Inoculum for infection was obtained from airborne conidia, discharged from the infected flowers. Symptoms, initially appeared as water-soaked brown lesion on the petals. Later, tan to grey, fuzzy mold, composed of thousands of spores, borne in grape like clusters covered the entire flower, under humid conditions. Fuzzy mold covered the flowers and flower buds and left them to choke. Under severe conditions, mold covers the 
entire plant and leads to complete drying. During prolonged period of sunshine without rain, irregular black resting bodies (sclerotia) of the fungus were found inside the split opened flowers (Fig. 1). In the present study, symptomatology results were in corroboration with earlier descriptions (Pie and De Leeuw, 1991).

Pathogenicity: In the present study, pathogenicity result in vitro revealed that 10 days after inoculation, the entire flower was covered by grey mycelial growth and also accompanied by black, irregular, flattened sclerotial bodies over the unopened calices. Under in vivo inoculated flower expressed typical symptom after 15 days. Infected flowers exhibited grey mycelial growth over the petals (Fig. 2). The fungus was re-isolated, from the plants expressing the typical symptoms. The reisolated fungus had similar characteristics of the previously studied fungus. Thus, Koch postulate was confirmed and pathogenicity results were in corroboration with the previous studies (Rivera and wright, 2002).

Morphological characterization : On Potato dextrose agar medium, the pathogen initially produced white mycelium, latter turned grey, indicating the production of numerous conidia. Ten days after incubation under complete darkness, dark, black, smooth surfaced irregular sclerotial bodies of various sizes and shapes were produced. The pathogen had hyaline, septate hyphae and produced grape bunch like conidia measuring $6.82 \mu \mathrm{m} \times 9.54 \mu \mathrm{m}$. Sclerotia germinated both by myceliogenous and sporogenous modes.

Previous study promulgate that $B$. aclada, $B$. alli and $B$. byssoidea do not produce sclerotia (Chilvers and Toit, 2006). This narrowed the identity of the pathogen to be $B$. squamosa or $B$. porri or $B$. fabae or $B$. cinerea. However, the test fungus was

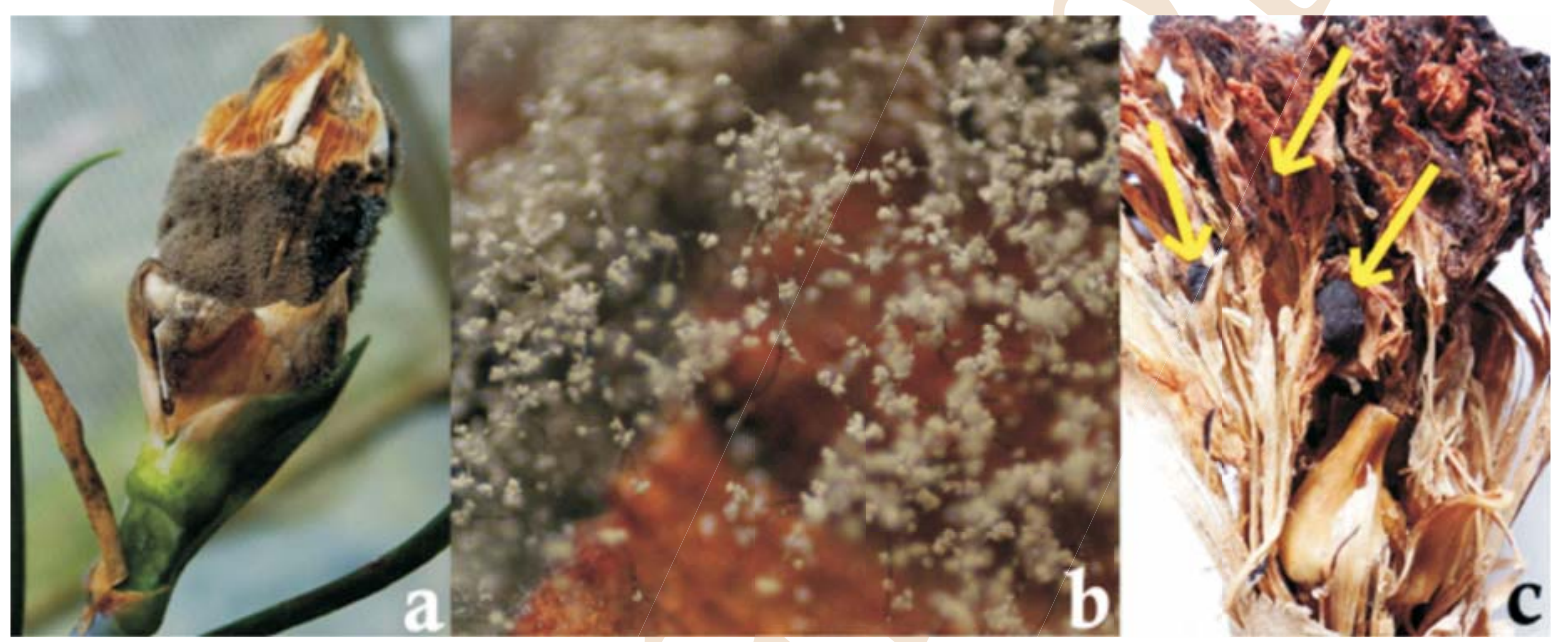

Fig. 1 : (a) Infected flower covered with fungal growth, (b) Grape bunch like appearance of conidiophore cluster, bearing conidia, (c) Sclerotial bodies inside split opened flower

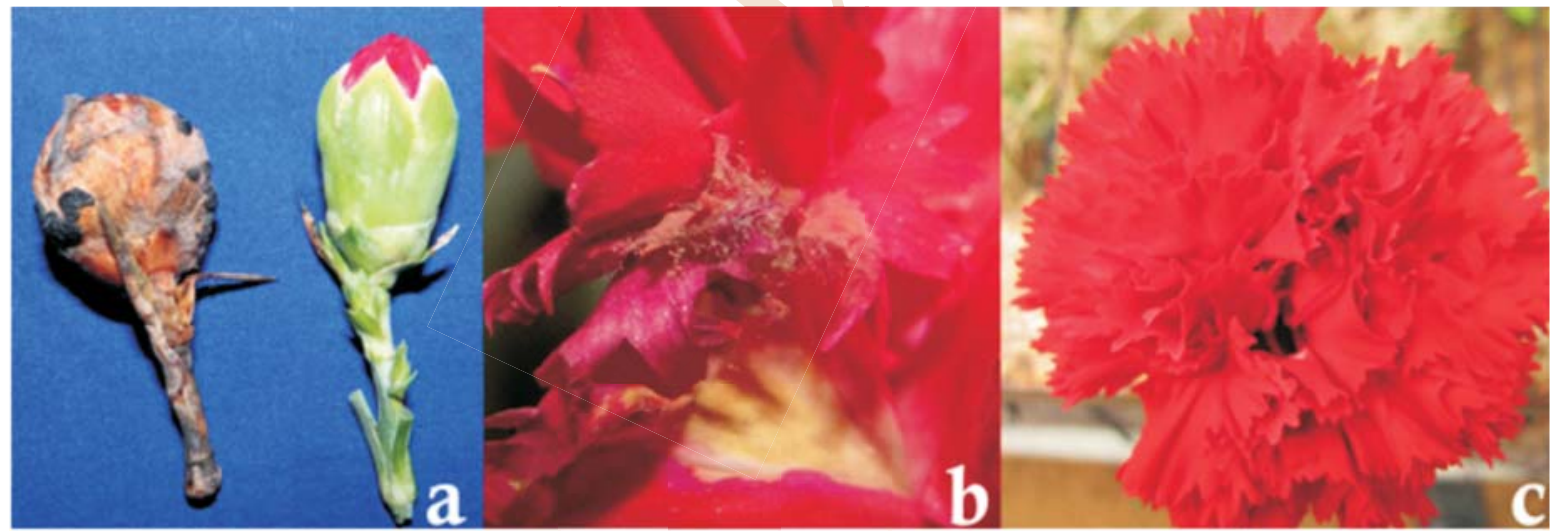

Fig. 2 : (a) Pathogenicity of inoculated flower under in vitro - inoculated and healthy flower, (b) Pathogenecity of inoculated flower under in vivo, (c) Healthy flower 


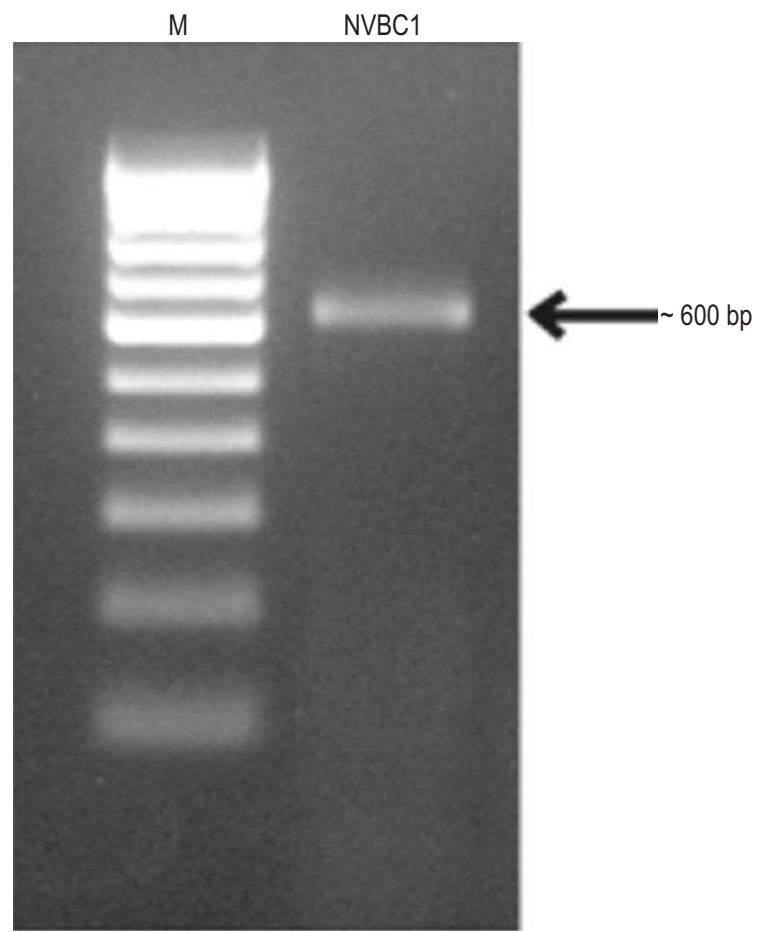

Fig. 3 : PCR amplification of 18S-28S rRNA gene of $B$. cinerea

Table 2 : Survey for the occurrence of blossom blight of carnation in Nilgiris district

\begin{tabular}{lll}
\hline Variety & Ooty & Kothagiri \\
\cline { 2 - 3 } & Blossom blight \% & Blossom blight \% \\
\hline Yellow liberty & 2.5 & 3.2 \\
Gaudina red & 8.6 & 9.4 \\
Farida & 0.0 & 2.3 \\
Bizet & 4.2 & 5.3 \\
Emotion white & 3.5 & 4.2 \\
Pintado & 4.5 & 4.6 \\
White liberty & 2.8 & 3.4 \\
Charmant pink & 5.8 & 6.4 \\
Pudding yellow & 3.2 & 3.5 \\
Baltico white & 2.1 & 2.6 \\
Mean incidence & 3.72 & 4.49 \\
\hline
\end{tabular}

differentiated from $B$. squamosa and $B$. fabae that produced comparatively smaller sclerotial bodies. $B$. cinera and $B$. porri produces larger sclerotial bodies, however the sclerotial bodies of $B$. porri are cerebriform and those of $B$. cinerea are smooth surfaced. The test fungus had fast relative growth rate, sporulated at $15^{\circ} \mathrm{C}$ and produced large, black, irregular, smooth surfaced sclerotia of various sizes. These parameters differentiated $B$. cinerea from other species. Hence, the pathogen $B$. cinerea was confirmed based on the above mentioned characteristic features (Chilvers and Toit, 2006).

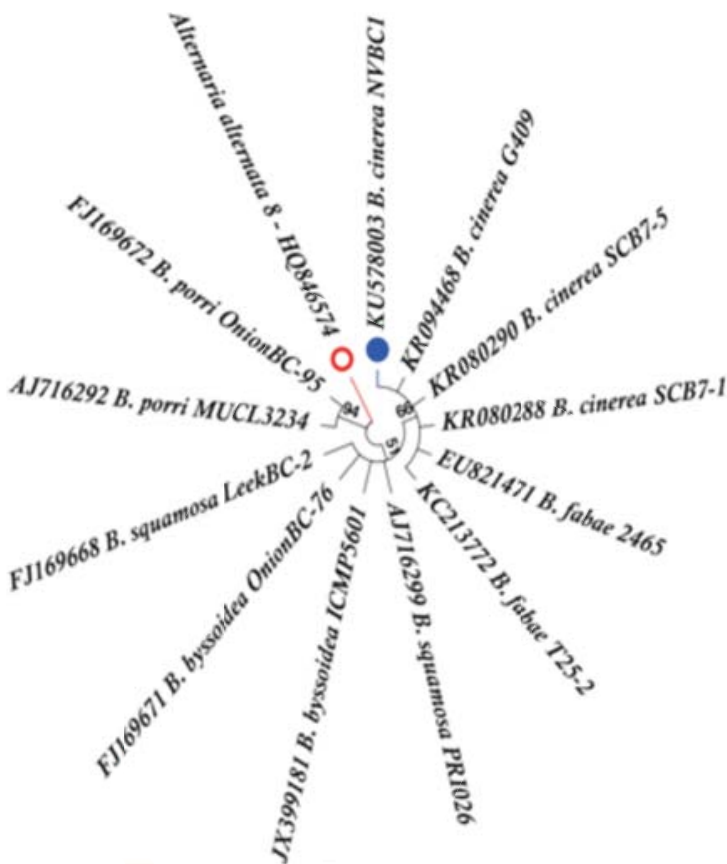

Fig. 4 : Phylogenetic tree of $18 S-28 S$ rRNA gene of $B$. cinerea analysed by MEGA6.0

Molecular characterization: The 18S-28S rRNA gene fragment of $B$. cinerea amplified at $600 \mathrm{bp}$ (approx), when visualized in $1.2 \%$ agarose (Fig. 3). The fragment was sequenced and submitted in NCBI - KU578003. The nucleotide sequence of 18S28S rRNA gene acquired from the study fungus showed $99 \%$ match with B. cinerea strains submitted in NCBI (KR094468). Further, in phylogenetic analysis (Mega 7.0), the study strain was grouped along with various strains of $B$. cinerea retrieved from $\mathrm{NCBI}$ with $66 \%$ similarity. This confirmed the identity of the pathogen as B. cinerea (Fig. 4).

Influence of environmental factors on growth parameters of B. cinerea: The relative growth rate of the fungus was fast at $15^{\circ} \mathrm{C}$ (Fig. 5). The pathogen produced larger and greater number of sclerotial bodies ( 56 nos) when incubated in complete darkness at $20^{\circ} \mathrm{C}$ (Fig. 6). Profuse sporulation $\left(9.67 \times 10^{6} / 9 \mathrm{~mm}\right.$ disc) was observed at $15^{\circ} \mathrm{C}$, when the fungus was incubated in alternate light and dark condition under high relative humidity (Fig. 6; Fig. 7). The mycelium metamorphsed to sclerotia by a series of process viz., gelatinization, compression and melanisation. (Fig. 8). Apart from the above treatments the mycelial growth, sporulation and sclerotial formation was relatively poor in others (Table 3).

Chilvers and Toit (2006) described that $B$. cinerea was relatively fast growing at $15{ }^{\circ} \mathrm{C}$. In the present study also the pathogen was fast growing and covered the entire plate within four days when incubated at $15^{\circ} \mathrm{C}$. It was also reported that the 


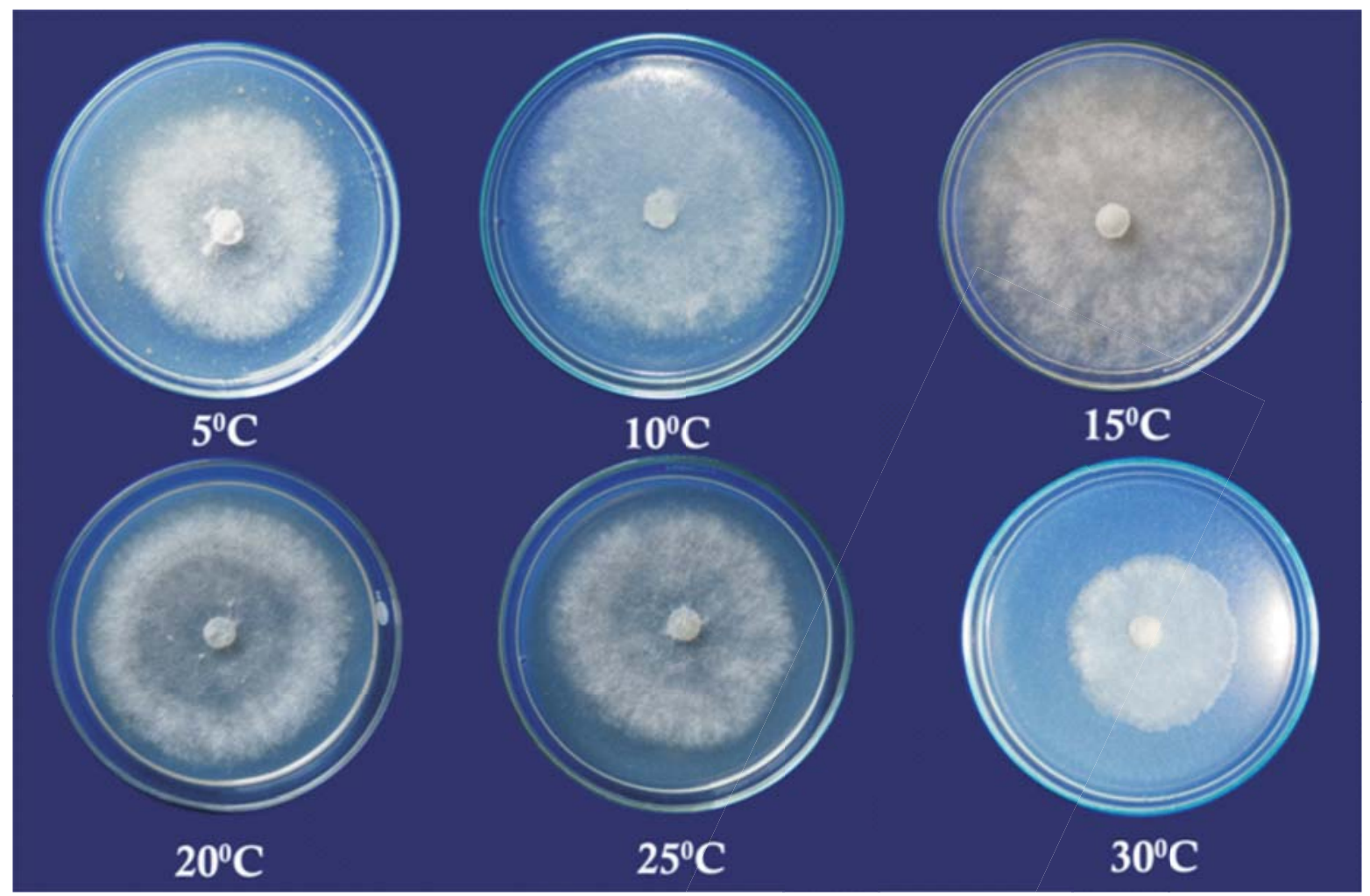

Fig. 5 : Effect of different temperatures on the mycelial growth of $B$. cinerea

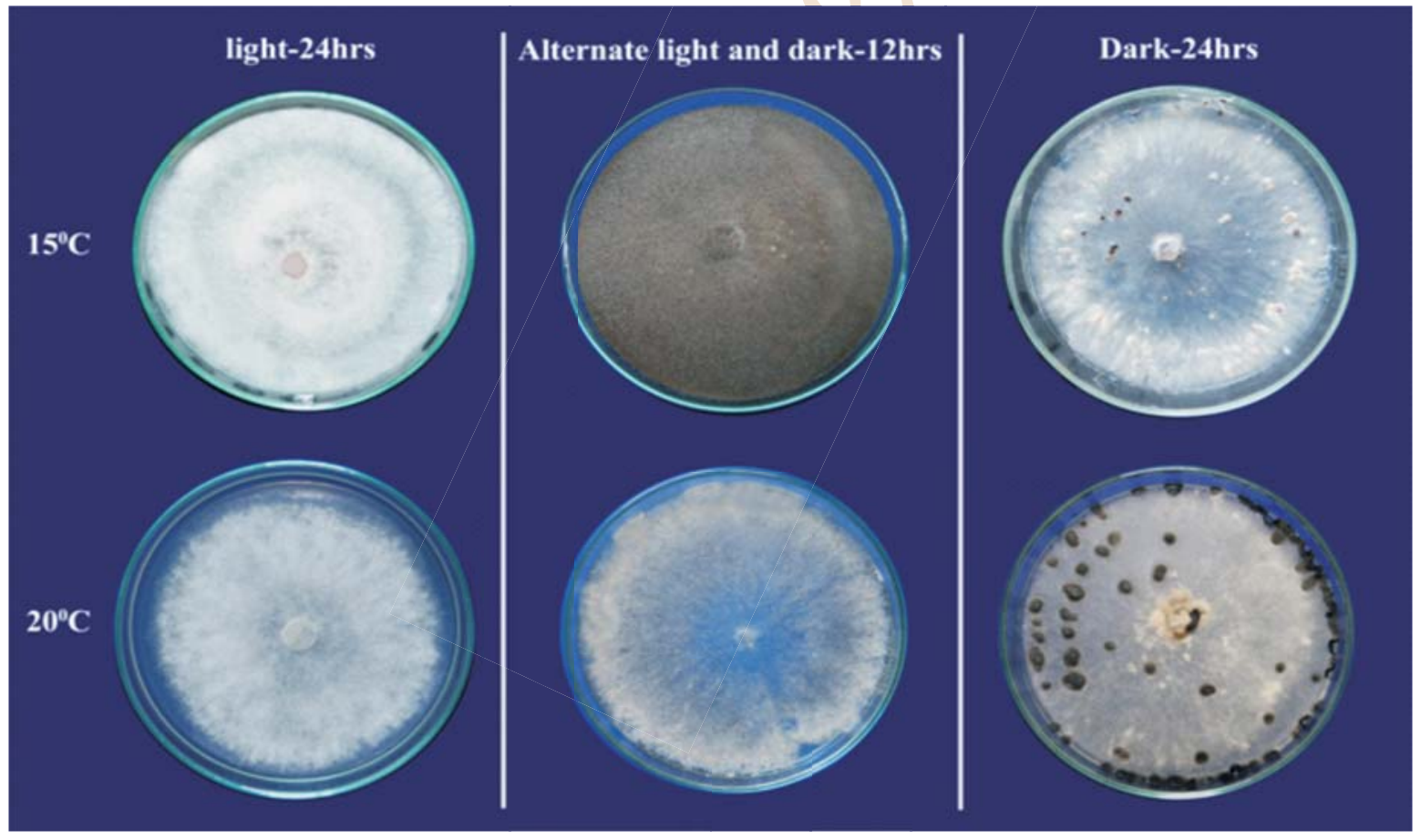

Fig. 6 : Effect of temperature and light in sporulation and sclerotial formation in B. cinerea 


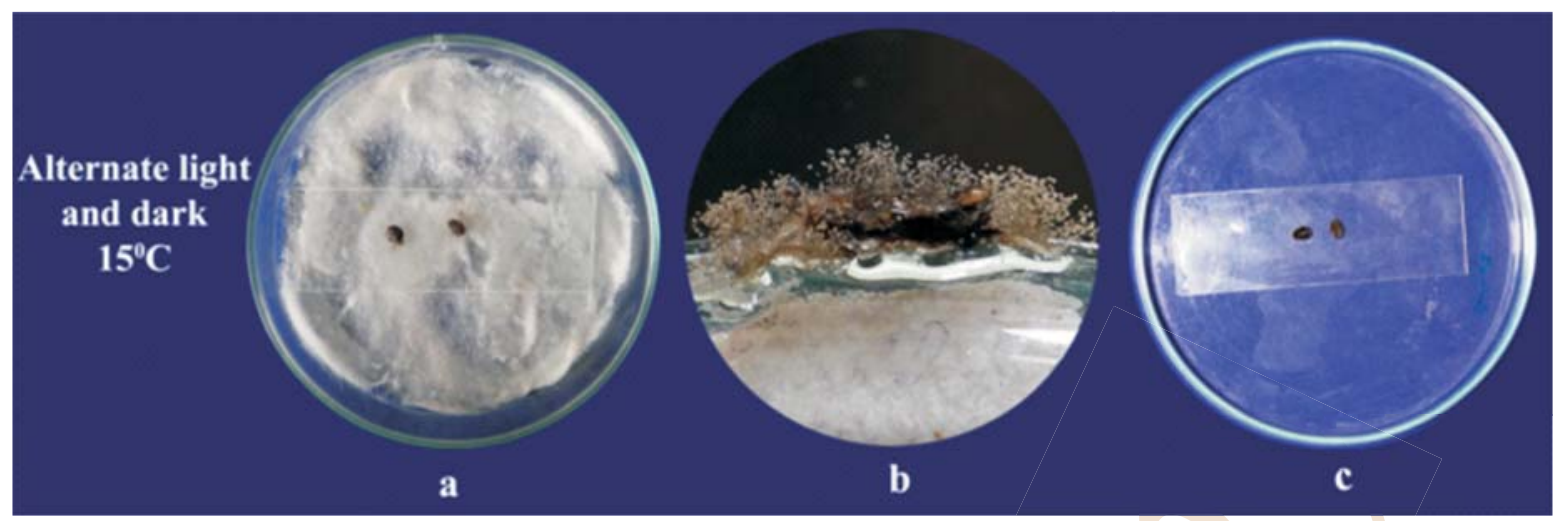

Fig. 7 : Effect of relative humidity and temperature in sporulating $B$. cinerea

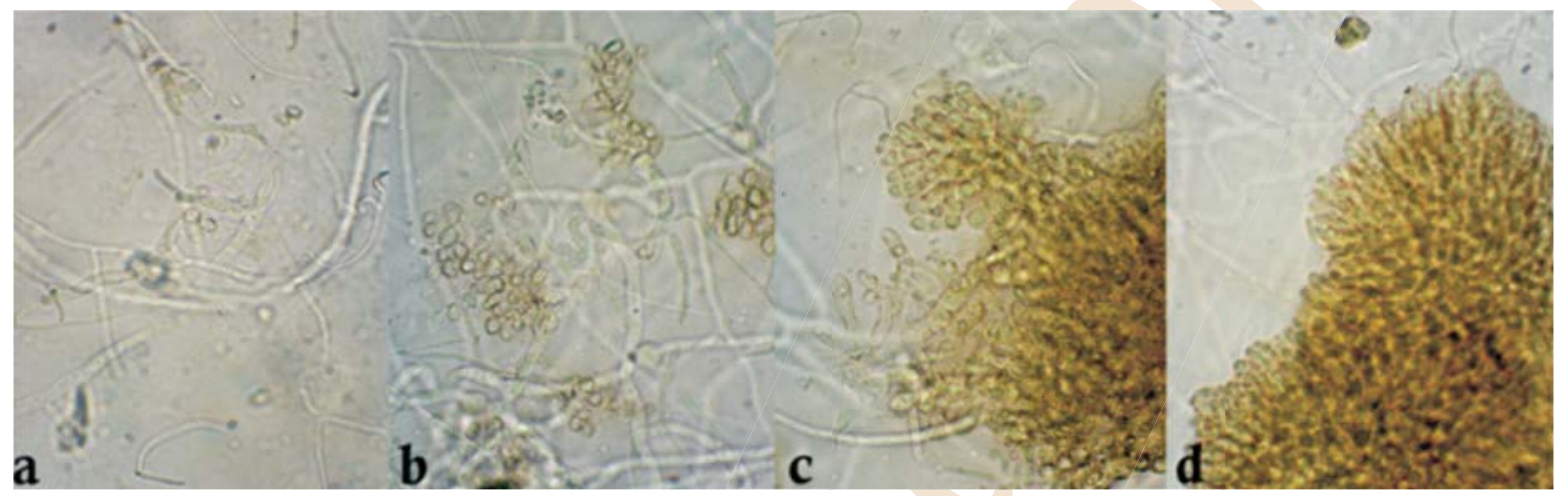

Fig. 8 : Developmental stages of sclerotia in $B$. cinerea (a) Gelatinization of hyphal wall $6^{\text {th }}$ day, (b) Compression and aggregation of hyphal cells into globose structures, (c) Melanization of tightly interwoven hyphal cells

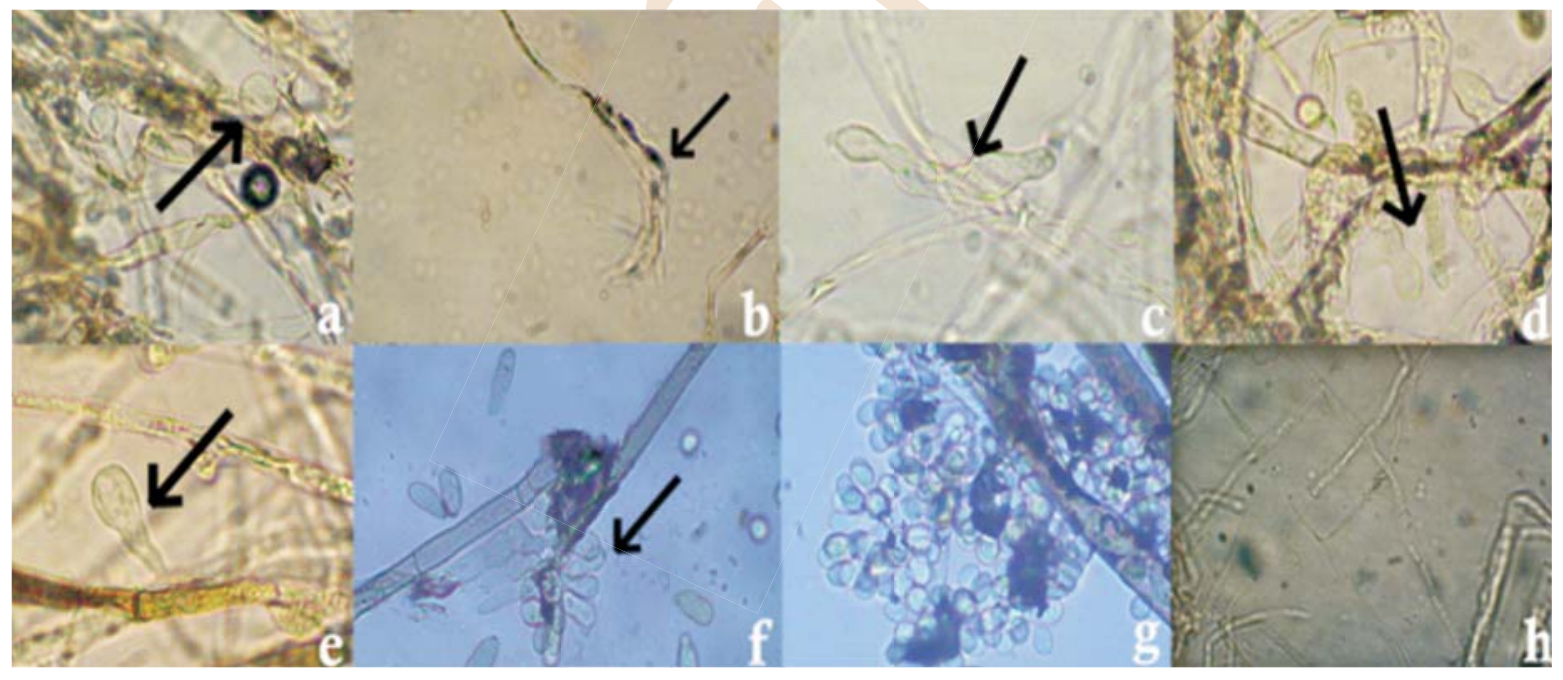

Fig. 9 : Mycelial malformation of $B$. cinerea due to the effect of various fungicides 
Table 3 : Influence of environmental factors on the growth parameters of $B$. cinerea

\begin{tabular}{|c|c|c|c|c|}
\hline Environmental factors & $\begin{array}{c}\text { Temperature } \\
\left({ }^{\circ} \mathrm{C}\right)\end{array}$ & $\begin{array}{l}\text { Mycelial growth } \\
(\mathrm{mm}) \text { after } 4 \text { days }\end{array}$ & $\begin{array}{l}\text { Sporulation } / 9 \mathrm{~mm} \\
\text { mycelial disc* }\end{array}$ & $\begin{array}{l}\text { No. of } \\
\text { sclerotia* }\end{array}$ \\
\hline \multirow[t]{6}{*}{ Cool white fluorescent light-(840W-24 hrs) } & 5 & 63.03 & - & - \\
\hline & 10 & 82.03 & - & - \\
\hline & 15 & 90.00 & - & - \\
\hline & 20 & 81.03 & - & - \\
\hline & 25 & 65.03 & - & - \\
\hline & 30 & 43.00 & - & - \\
\hline \multirow[t]{6}{*}{ Darkness (24 hrs) } & 5 & 62.03 & - & - \\
\hline & 10 & 83.03 & - & - \\
\hline & 15 & 90.00 & $1.5 \times 10^{5}$ & 25.66 \\
\hline & 20 & 82.03 & - & 53.33 \\
\hline & 25 & 66.03 & - & - \\
\hline & 30 & 45.00 & - & - \\
\hline \multirow[t]{6}{*}{ Alternate lightand dark period ( $12 \mathrm{hrs}$ ) } & 5 & 61.03 & - & - \\
\hline & 10 & 81.03 & - & - \\
\hline & 15 & 90.00 & $9.67 \times 10^{5}$ & - \\
\hline & 20 & 83.03 & - & - \\
\hline & 25 & 67.03 & - & - \\
\hline & 30 & 46.00 & - & - \\
\hline \multirow[t]{2}{*}{ Relative humidity $\%\left(15^{\circ} \mathrm{C}+\right.$ Alternate light $)$} & $>96 \%$ & - & + & - \\
\hline & 0 & - & - & - \\
\hline
\end{tabular}

Note: $+\rightarrow$ Induction of sporogenous germination, - $\rightarrow$ Absence; *Values are mean of three replications

optimum sporulating temperature of $B$. cinerea was $15^{\circ} \mathrm{C}$. Alvarez et al. (1995) reported that the optimum temperature for sporulation was between $17^{\circ} \mathrm{C}$ and $18^{\circ} \mathrm{C}$ with continuous wetting. Chilvers and Toit (2006) reported that the pathogen sporulated in alternate light and dark cycles only. Similarly in the present study, the pathogen sporulated when incubated at $15^{\circ} \mathrm{C}$ of alternate light and dark cycles with continuous wetting. But, when the pathogen was exposed to similar conditions of light and temperature without wetting, no sporulation was observed. Besides, the pathogen failed to sporulate even if any one of the factors were unfavourable. This denotes the synergistic, influential effect of temperature, light and relative humidity in sporulation. Production of scleerotia in dark has been reported in earlier studies (Chilvers and Toit, 2006; Tan and Eptonh, 1973). Zhang et al. (2010) reported that $B$. cinerea produced sclerotia when exposed to complete darkness at $25^{\circ} \mathrm{C}$. In the present study, the pathogen produced sclerotial bodies, when incubated in complete darkness at $20^{\circ} \mathrm{C}$ for 10 days. B. cinerea sporulated at $15^{\circ} \mathrm{C}$ when incubated at high relative humidty with alternate light and dark cycles. The results of the study regarding the influence of environmental conditions, over the growth parameters of $B$. cinerea were in corroboration with the earlier works (Chilvers and Toit, 2006; Tan and Eptonh, 1973; Zhang et al., 2010).

In vitro efficacy of fungicides against the growth of Botrytis cinerea: Results indicated that tebuconazole 250 EC and difenaconazole $25 \%$ EC recorded $100 \%$ inhibition of mycelial growth at 5ppm. Propineb 70 WP inhibited mycelial growth at 250 ppm followed by propiconazole 25\% EC inhibited mycelial growth at 1000ppm. But, other fungicides viz., azoxystrobin 25\% SC and carbendazim 50\% WP were not effective in inhibiting the mycelial growth of $B$. cinerea till 1000 ppm (Table 3). Disintegration, swelling and abnormal conidial shapes were observed in the hyphae and conidia of $B$. cinerea under microscope, when cultured in the fungicide amended plates compared to the healthy control (Fig. 9).

Botrytis has been reported to exhibit resistance against benzimidazole group and quinol oxidation inhibiting fungicides (Barro et al., 2008; Wedge et al., 2007). Similarly in the present study, growth of the pathogen was not inhibited by carbendazim, azoxystrobin. In the present study, tebuconazole, difenoconozole and propiconozole were effective in inhibiting the mycelial growth of the pathogen in vitro. In the present study, the pathogen was inhibited to some extent with propineb, which was in corroboration with the work of Leroux (2007), who reported control of Botrytis by dithiocarbamates.

Yang et al. (2011) reported that azole group of fungicides targets the membrane compounds like lipid and sterol. In our study, when the mycelium of $B$. cinerea was exposed to azole fungicides, they showed mycelial malformations viz., swellings and disintegration. This might have been due to the action of azole group fungicides over the membrane of the pathogens as discussed in the above statements. 
Table 4 : In vitro efficacy of fungicides against $B$. cinerea

\begin{tabular}{|c|c|c|c|c|c|c|c|c|c|c|}
\hline Fungicides & Growth parameters & $1 \mathrm{ppm}$ & $5 p p m$ & 10ppm & $25 \mathrm{ppm}$ & $50 \mathrm{ppm}$ & $100 \mathrm{ppm}$ & 250ppm & $500 \mathrm{ppm}$ & $1000 \mathrm{ppm}$ \\
\hline Carbendazim & Mycelial growth $(\mathrm{mm})^{*}$ & $90.00^{d}$ & $90.00^{d}$ & $90.00^{d}$ & $90.00^{d}$ & $90.00^{d}$ & $90.00^{d}$ & $90.00^{\circ}$ & $90.00^{d}$ & $90.00^{d}$ \\
\hline \multirow[t]{2}{*}{$50 \% \mathrm{WP}$} & & $(71.61)$ & (71.61) & (71.61) & $(71.61)$ & $(71.61)$ & $(71.61)$ & $(71.61)$ & (71.61) & (71.61) \\
\hline & $\begin{array}{l}\text { Percent inhibition of mycelial } \\
\text { growth over control }\end{array}$ & 0.00 & 0.00 & 0.00 & 0.00 & 0.00 & 0.00 & 0.00 & 0.00 & 0.00 \\
\hline \multirow[t]{2}{*}{$\begin{array}{l}\text { Tebuconazole } \\
250 \text { EC }\end{array}$} & Mycelial growth $(\mathrm{mm})^{*}$ & $\begin{array}{l}18.03^{\mathrm{a}} \\
(25.12)\end{array}$ & $\begin{array}{l}0.00^{\mathrm{a}} \\
(3.82)\end{array}$ & $\begin{array}{l}0.00^{\mathrm{a}} \\
(3.82)\end{array}$ & $\begin{array}{l}0.00^{\mathrm{a}} \\
(3.82)\end{array}$ & $\begin{array}{l}0.00^{\mathrm{a}} \\
(3.82)\end{array}$ & $\begin{array}{l}0.00^{\mathrm{a}} \\
(3.82)\end{array}$ & $\begin{array}{l}0.00^{\mathrm{a}} \\
(3.82)\end{array}$ & $\begin{array}{l}0.00^{\mathrm{a}} \\
(3.82)\end{array}$ & $\begin{array}{l}0.00^{\mathrm{a}} \\
(3.82)\end{array}$ \\
\hline & $\begin{array}{l}\text { Percent inhibition of mycelial } \\
\text { growth over control }\end{array}$ & 80.00 & 100.00 & 100.00 & 100.00 & 100.00 & 100.00 & 100.00 & 100.00 & 100.00 \\
\hline \multirow[t]{2}{*}{$\begin{array}{l}\text { Difenoconazole } \\
25 \% \text { EC }\end{array}$} & Mycelial growth $(\mathrm{mm})^{*}$ & $\begin{array}{l}17.03^{\mathrm{a}} \\
(24.37)\end{array}$ & $\begin{array}{l}0.00^{\mathrm{a}} \\
(3.82)\end{array}$ & $\begin{array}{l}0.00^{\mathrm{a}} \\
(3.82)\end{array}$ & $\begin{array}{l}0.00^{\mathrm{a}} \\
(3.82)\end{array}$ & $\begin{array}{l}0.00^{\mathrm{a}} \\
(3.82)\end{array}$ & $\begin{array}{l}0.00^{\mathrm{a}} \\
(3.82)\end{array}$ & $\begin{array}{l}0.00^{\mathrm{a}} \\
(3.82)\end{array}$ & $\begin{array}{l}0.00^{\mathrm{a}} \\
(3.82)\end{array}$ & $\begin{array}{l}0.00^{\mathrm{a}} \\
(3.82)\end{array}$ \\
\hline & $\begin{array}{l}\text { Percent inhibition of mycelial } \\
\text { growth over control }\end{array}$ & 81.11 & 100.00 & 100.00 & 100.00 & 100.00 & 100.00 & 100.00 & 100.00 & 100.00 \\
\hline \multirow[t]{2}{*}{$\begin{array}{l}\text { Propineb } \\
70 \text { WP }\end{array}$} & Mycelial growth $(\mathrm{mm})^{*}$ & $\begin{array}{l}87.03^{\circ} \\
(68.90)\end{array}$ & $\begin{array}{l}73.03^{\mathrm{c}} \\
(58.72)\end{array}$ & $\begin{array}{l}65.03^{\circ} \\
(53.75)\end{array}$ & $\begin{array}{l}54.03^{\mathrm{c}} \\
(53.15)\end{array}$ & $\begin{array}{l}48.03^{\mathrm{c}} \\
(53.56)\end{array}$ & $\begin{array}{l}42.03^{\mathrm{c}} \\
(40.42)\end{array}$ & $\begin{array}{l}0.00^{\mathrm{a}} \\
(3.82)\end{array}$ & $\begin{array}{l}0.00^{\mathrm{a}} \\
(3.82)\end{array}$ & $\begin{array}{l}0.00^{\mathrm{a}} \\
(3.82)\end{array}$ \\
\hline & $\begin{array}{l}\text { Percent inhibition of mycelial } \\
\text { growth over control }\end{array}$ & 3.33 & 18.89 & 27.78 & 39.97 & 46.63 & 53.33 & 100.00 & 100.00 & 100.00 \\
\hline \multirow[t]{2}{*}{$\begin{array}{l}\text { Propiconazole } \\
25 \% \text { EC }\end{array}$} & Mycelial growth $(\mathrm{mm})^{*}$ & $\begin{array}{l}57.03^{\mathrm{b}} \\
(49.04)\end{array}$ & $\begin{array}{l}54.03^{b} \\
(47.31)\end{array}$ & $\begin{array}{l}51.03^{b} \\
(45.59)\end{array}$ & $\begin{array}{l}50.03^{\mathrm{b}} \\
(45.02)\end{array}$ & $\begin{array}{l}43.03^{\mathrm{b}} \\
(40.99)\end{array}$ & $\begin{array}{l}40.03^{b} \\
(39.25)\end{array}$ & $\begin{array}{l}39.03^{b} \\
(38.66)\end{array}$ & $\begin{array}{l}21.03^{\mathrm{b}} \\
(27.29)\end{array}$ & $\begin{array}{l}0.00^{\mathrm{a}} \\
(3.82)\end{array}$ \\
\hline & $\begin{array}{l}\text { Percent inhibition of mycelial } \\
\text { growth over control }\end{array}$ & 36.67 & 40.00 & 43.33 & 44.44 & 52.22 & 55.56 & 56.67 & 76.67 & 100.00 \\
\hline \multirow[t]{2}{*}{$\begin{array}{l}\text { Azoxystrobin } \\
25 \% \text { SC }\end{array}$} & Mycelial growth $(\mathrm{mm})^{*}$ & $\begin{array}{l}90.00^{d} \\
(71.61)\end{array}$ & $\begin{array}{l}90.00^{d} \\
(71.61)\end{array}$ & $\begin{array}{l}90.00^{d} \\
(71.61)\end{array}$ & $\begin{array}{l}90.00^{d} \\
(71.61)\end{array}$ & $\begin{array}{l}90.00^{d} \\
(71.61)\end{array}$ & $\begin{array}{l}90.00^{d} \\
(71.61)\end{array}$ & $\begin{array}{l}90.00^{\circ} \\
(71.61)\end{array}$ & $\begin{array}{l}90.00^{d} \\
(71.61)\end{array}$ & $\begin{array}{l}90.00^{d} \\
(71.61)\end{array}$ \\
\hline & $\begin{array}{l}\text { Percent inhibition of mycelial } \\
\text { growth over control }\end{array}$ & 0.00 & 0.00 & 0.00 & 0.00 & 0.00 & 0.00 & 0.00 & 0.00 & 0.00 \\
\hline Control & $\begin{array}{l}\text { Mycelial growth }(\mathrm{mm})^{*} \\
\text { Percent inhibition of mycelial } \\
\text { growth over control }\end{array}$ & \multicolumn{9}{|c|}{$90.00^{d}(71.61)$} \\
\hline
\end{tabular}

*Values are mean of three replications; Means followed by a common letter are not significantly different at $5 \%$ level by DMRT; Values in parenthesis are square root transformed values

Table 5 : Efficacy of fungicides against $B$. cinerea under protected cultivation

\begin{tabular}{|c|c|c|c|c|c|}
\hline \multirow[t]{2}{*}{ Foliar spray @0.15\% } & \multirow[t]{2}{*}{ No. shoots/plant } & \multirow{2}{*}{$\begin{array}{l}\text { Length of flower stalk* } \\
\qquad(\mathrm{cm})\end{array}$} & \multicolumn{2}{|c|}{ Flower yield* } & \multirow[b]{2}{*}{ Healthy flowers per $\mathrm{m}$} \\
\hline & & & Numbers per $\mathrm{m}$ & Infected flowers per m & \\
\hline Carbendazim 50\% WP & $4.59^{d}(12.33)$ & $60.32^{\mathrm{e}}(50.96)$ & $137.33 \mathrm{e}(11.72)$ & $54.00 \mathrm{f}(7.41)$ & $83.33 \mathrm{e}(9.13)$ \\
\hline Tebuconazole 250 EC & $5.54^{\mathrm{a}}(13.58)$ & $71.41^{\mathrm{a}}(57.68)$ & $215.00 \mathrm{a}(14.66)$ & $11.00 \mathrm{a}(3.45)$ & $200.33 \mathrm{a}(14.15)$ \\
\hline Difenoconazole $25 \%$ EC & $5.41^{\mathrm{a}}(13.42)$ & $68.97^{b}(56.15)$ & $200.67 b(14.16)$ & $16.33 \mathrm{~b}(4.16)$ & $180.33 \mathrm{~b}(13.43)$ \\
\hline Propineb 70 WP & $4.85^{\circ}(12.68)$ & $62.20^{\mathrm{d}}(52.06)$ & $178.33 c(13.35)$ & $23.67 c(44.96)$ & $152.67 \mathrm{c}(12.36)$ \\
\hline Propiconazole 25\% EC & $5.16^{b}(13.09)$ & $66.76^{\circ}(54.80)$ & $197.00 \mathrm{~b}(14.03)$ & $37.33 \mathrm{~d}(6.19)$ & $155.00 \mathrm{c}(12.45)$ \\
\hline Azoxystrobin $25 \%$ SC & $4.31^{\circ}(11.93)$ & $58.47^{\prime}(49.88)$ & $163.00 \mathrm{~d}(12.77)$ & $48.67 \mathrm{e}(7.04)$ & $132.33 \mathrm{~d}(11.50)$ \\
\hline Control & $3.64^{f}(10.94)$ & $57.00^{f}(49.03)$ & $128.67 f()$ & $58.33 \mathrm{~g}(7.70)$ & $68.67 f(8.28)$ \\
\hline
\end{tabular}

*Values are mean of three replications; Means followed by a common letter are not significantly different at $5 \%$ level by DMRT; Values in parenthesis are square root transformed values

Efficacy of fungicides against $B$. cinerea under protected cultivation: Foliar spray with tebuconazole 250 EC @ 0.15\% (1.5 $\mathrm{ml} \mathrm{I}^{-1}$ ) (T2) - reduced blossom blight incidence up to $5.71 \%$ compared to other fungicides and was relatively lesser compared to control $(46.46 \%)$. Moreover, the number of healthy flowers per $\mathrm{m}^{2}$ was also greater in the beds treated with tebuconazole 250 EC. Followed by, difenoconazole 25\% EC @ 0.15\% controlled the disease incidence and increased the number of marketable blooms. Fungicides like propineb 70WP, propiconazole 25\% EC reduced the disease intensity to lesser extent. Disparately, 
carbendazim $50 \%$ WP and azoxystrobin $25 \%$ SC were ineffective and showed no improvement in disease reduction and were on par with untreated control (Table 4).

Stenersen (2004) reported that resistance of $B$. cinerea against carbendazim was due to the lower binding ability of fungicide molecule to the active sites on $\beta$-tubulin, which might be due to the mutational changes in amino acids viz., valine with alanine or phenylalanine with tyrosine. Similarly, in the present study, $B$. cinerea were resistant against carbendazim, which might be due to the mutational changes in amino acids, fundamentally leading to resistance. Asadollahi et al. (2013) reported resistance of $B$. cinerea against quinol oxidation inhibitor fungicide azoxystrobin. The fungicide molecule binds to cytb gene responsible for cytochrome bc1 complex, there by blocking electron transport and ATP synthesis. But, in case of mutational change of amino acids in cytb gene, the binding ability of the fungicide molecule reduces and resistance is exhibited. In the present study azoxystrobin was not effective against $B$. cinerea. This might be due to the mutational changes in relation to the previous studies. Difenoconazole has been used as the most efficient triazole fungicide in the control of several plant diseases (Xu et al., 2004). Many triazole compounds have good fungicidal and plant growth regulating activities viz., root elongation, increasing the number of lateral roots, increase in chlorophyll content and photosynthesis activity (Fletcher et al., 2000; Tuna, 2014). Tebuconazole effectively inhibited $B$. cinerea in grapes (Nagehan et al., 2012), chick pea (Hahiduzzaman, 2015). In relation to the above mentioned studies, azole group of fungicides exhibited good control over the growth of the pathogen. In the present study, tebuconazole was found effective in restricting the growth of the pathogen as well as resulted in promotion of plant growth.

Blossom blight caused by $B$. cinerea is ravaging and an important disease due to which the aesthetic value of the flower is completely lost. This study throws light on the influence of environmental factors in the developmental biology and establishment of the pathogen. Future studies, on the management of blossom blight by breaking the developmental biology, will provide complete solution to the menace. Utilization of azole fungicides in the management of blossom blight will curtail the disease incidence to maximum extent.

\section{Acknowledgments}

The authors would like to thank Prof. A.S. Krishnamoorthy, Professor and Head of the Department of Plant Pathology and Dr. S. Mohan, The Dean (SPGS), Tamil Nadu Agricultural University. We would also like to acknowledge DSTFIST(Department of Science and Technology), New Delhi for the infra-structure facilities.

\section{References}

Alvarez, M., L.V. Madden and M.A. Ellis: Effects of temperature and wetness duration on sporulation of Botrytis cinerea on strawberry leaf surfaces. Plant Dis.,79, 609-615 (1995).

Asadollahi, M., A. Szojka, E. Fekete, L. Karaffa, F. Takács, M. Flipphi and E. Sándor: Resistance to Qol fungicide and Cytochrome $b$ diversity in the Hungarian Botrytis cinerea population. J. Agr. Sci. Tech., 15, 397-407 (2013).

Banno, S., F. Fukumori and A. Ichiishi: Genotyping of Benzimidazole resistant and Dicarboximide-resistant mutations in Botrytis cinereausing Real-time Polymerase Chain Reaction Assays. Phytopathology, 98, 397-404 (2008).

Chakraborty, B.N., U. Chakraborty, A. Saha, P.L. Dey and K. Sunar: Molecular characterization of Trichoderma viride and Trichoderma harzianum isolated from soils of North Bengal based on rDNA markers and analysis of their PCR-RAPD profiles. Glob. J. Biotech. Biochem., 5, 55-61(2010).

Chilvers, M.I. and L.J. Toit: Detection and identification of Botrytis species associated with neck rot, scape blight, and umbel blight of onion. Plant Hlth. Prog., doi:10.1094/PHP-2006-1127-01-DG (online) (2006).

Dennis, C. and J. Webster: Antogonistic properties of species group of Trichoderma production of non-volatile antibiotics. T. Brit. Mycol. Soc., 57, 25-39 (1971)

Fletcher, R.A., A. Gill, T.D. Davis and N. Sankhla: Triazoles as plant growth regulators and stress protectants. Hortic. Rev., 24, 55-138 (2000).

Hahiduzzaman, M.: Efficacy of fungicides in controlling botrytis gray mold of chickpea (Cicer arietinum L.) Bangladesh J. Agric. Res., 40, 391-398 (2015).

Hennebert, G.L.: Botrytis and Botrytis-like genera. Persoonia., 7, 183-204 (1973).

Jarvis, W.R.: Botryotinia and Botrytis species: Taxonomy, Physiology and Pathogenicity. A Guide to the Literature. Monograph No. 15, Canada Department of Agriculture, Ottawa, Canada (1977).

Jarvis, W.R.: Epidemiology. In: The Biology of Botrytis (Eds.: J.R. ColeySmith, K. Verhoeff and W.R. Jarvis). Academic Press, London, UK, pp. 219-250 (1980).

Leroux, P.: Chemical control of Botrytis and its resistance to chemical fungicides. In: Botrytis: Biology, Pathology and Control. (Eds.: Y. Elad, B. Williamson, P. Tudzynski and N. Delen). Kluwer Acedemic Publishers, The Netherlands, pp. 195-222 (2007).

Liang, Z.X., S.S. Zhang, S.Y. Niu, Y.Q. Qin, X.M. Li and K. Jiao: Synthesis and biological activities of novel Triazole compounds containing 1 , 3-Dioxolane rings. Moleculesm., 9, 913-921 (2004).

Nagehan, D.K., O. Nuray and D. Nafiz: Sensitivity of Botrytis cinerea isolates against some fungicides used in vineyards. Afr. J. Biotechnol., 11, 1892-1899 (2012).

Pie, K. and G.T.N. De Leeuw: Histopathology of the initial stages of the interaction between rose flowers and Botrytis cinerea. Netherlands. J. Plant Pathol., 97, 335-344 (1991).

Presly, A.H.: Studies of Botrytis spp. occurring on onions (Allium cepa) and leeks (Allium porrum). Plant Pathol., 34, 422-427 (1985).

Rivera, M.C. and E.R. Wright: First report of blight caused by Botrytis cinerea on china rose in Argentina. Plant Hlth. Prog., doi:10.1094/PHP-2002-0322-01-HN (Online) (2002).

Saitoh, K., K. Togashi and T.A.T. Teraoka: A simple method for mini- 
preparation of fungal DNA. J. Gen. Plant Pathol., 72, 348-350 (2006).

Stenersen, J.: Chemical pesticides mode of action and toxicology. CRC press, Florida, p. 231 (2004)

Tan, K.K. and A.S. Eptonh: Effect of light on the growth and sporulation of Botrytis cinerea. T. Brit. Mycol. Soc., 61, 145-157 (1973).

Tuna, A.L.: Influence of foliarly applied different triazole compounds on growth, nutrition and antioxidant enzyme activities in tomato (Solanum lycopersicum L.) under salt stress. Aust. J. Crop Sci., 8, 71-79 (2014).

Wedge, D.E., B.J. Smith, J.P. Quebedeaux and R.J. Constantin: Fungicide management strategies for control of strawberry fruit rot diseases in Louisiana and Mississippi. Crop Protection, 26, 14491458 (2007).

Wheeler, B.E.: An Introduction to Plant Diseases. John Willey and Sons Ltd., London, p. 301 (1969).

White, T.J., T. Bruns, S. Lee and J. Taylor: Amplification and direct sequencing of fungal ribosomal RNA genes for phylogenetics. In: PCR protocols: A guide to methods and applications (Eds.: M.A. Innis, D.H. Gelfand and J.J. Sninsky). Academic Press London, UK. pp. 315-322 (1990).

Williamson, B., B. Tudzynski, P. Tudzynski and J.A. Van kan: Botrytis cinerea: The cause of grey mould disease. Mol. Plant Pathol., 8 , 561-580 (2007).

Yang, C., C. Hamel, V. Vujanovic and Y. Gan: Fungicide: Modes of action and possible impact on nontarget microorganisms. ISRN Ecology, 2011, 130289 (2011).

Yohalem, D.S., K. Nielsen and M. Nicolaisen: Taxonomic and nomenclatural clarification of the onion neck rotting Botrytis species. Mycotaxon, 85, 175-182 (2003).

Zhang, J., M.D. Wu, G.Q. Li, L. Yang and D.H. Jiang: Botrytis fabiopsis, a new species causing chocolate spot of broad bean in Central China. Mycologia, 102, 1114-1126 (2010). 